\title{
Understanding Tenure Security, Infrastructure and Livelihoods Nexus in Slum Upgrading
}

\author{
Peris Korir Mangíra* Musyimmi Mbathi Samuel Obiero \\ School of Built Environment, University of Nairobi, 30197, 00100, Nairobi , Kenya
}

\begin{abstract}
The economic, social and environmental challenges associated with the proliferation of informal settlements in the urban space, especially in the global south, are extensively documented and acknowledged. Slum or informal settlement upgrading has been seen as the current best redress mechanism. However, its potential to do so especially in meeting the target of making cities and human settlements inclusive, safe, resilient and sustainable by 2030 is constrained by sectoral approaches and limited appreciation of linkages in upgrading interventions in addition to an overemphasis on physical more than people centred interventions. Understanding linkages and interrelationships in upgrading interventions are critical for integration, coordination, synergy and sustainability and so are wellbeing aspects in achieving balanced development. However, there is limited knowledge on these and this study sought to contribute to this knowledge gap by investigating linkages in upgrading interventions with a specific focus on tenure security, infrastructure and livelihoods improvements. Based on case study fieldwork undertaken in Eldoret, the fifth largest town in Kenya and qualitative and quantitative data analysis, the paper argues that there is a nexus in tenure security, infrastructure and livelihoods improvement in upgrading. This calls for rethinking the current dominant single approach to upgrading in favor of multisector, integrated and linked up approaches that capitalise on synergies while minimizing trade-offs and interweaving human and physical elements in upgrading for greater impact and sustainability. Understanding how the tenure, infrastructure and livelihoods upgrading interventions are interlinked and the dynamics therein are crucial to the policy and practice of upgrading.
\end{abstract}

Keywords-Tenure security,Infrastructure, Livelihoods, Linkages, Upgrading

DOI: $10.7176 /$ RHSS/9-8-12

Publication date: April $30^{\text {th }} 2019$

\section{Introduction}

The search for solutions to challenges arising from the proliferation of informal settlements has gained prominence in the global development agenda and so has the significance of slum upgrading as part of the solution. An estimated 1 billion people across the world live in these deplorable conditions (UN-Habitat, 2016) and the number is rising. Efforts to reverse this trend through the Millennium Development Goals (MDGs) reduced the number from 46.2 per cent in 1990 to 29.7 per cent in 2014. The current global development agenda, the Sustainable Development Goals (SDGs) is building on these achievements by targeting to upgrade slums by 2030. However, slum upgrading has sometimes failed to achieve the intended purpose. Among the challenges are first, compartmentalized approaches owing to limited understanding of linkages within and amongst upgrading interventions and secondly overemphasis on physical and not human improvements. These pathways potentially constrain upgrading outcomes. Using field research, this paper seeks to contribute to this knowledge gap by examining the nexus of slum upgrading interventions, specifically the interventions of tenure security, infrastructure, and livelihoods improvement. The study was undertaken in Eldoret, the fifth largest town in Kenya characterised by high urban growth rate and increasing informality in its urban areas. Some of the informal settlements have however benefitted from upgrading and three of these, namely Huruma, Munyaka and Kamkunji were purposely identified since they presented an opportunity of achieving the research objective. The study obtained primary data through a household survey, focus group discussions, key informant interviews, field observations and secondary data from existing documents. Data were analysed through qualitative and quantitative techniques. The findings suggest that the interventions of tenure security, infrastructure and livelihoods are intrinsically linked both in processes and outcomes and that livelihoods are a neglected component in upgrading. The study, therefore, suggests there is a need for integrated rather than silo approaches and the need to put people at the centre of upgrading through the incorporation of livelihoods in the physical upgrading interventions, for greater impact and sustainability. This is with a view to informing policy and practise that will make upgrading more responsive to the needs of the urban poor.

\section{Theoretical underpinning and literature review}

This section explores theoretical and empirical literature on tenure security, infrastructure, livelihoods and their interlinkages, in upgrading. It emerges that most of these studies have focused on the significance of each of these elements but limited on their inter-linkages, a gap that this research is contributing to. 


\subsection{Tenure Security}

Tenure Security, defined as 'an agreement between individuals or groups, with respect to land and residential property, that is governed and regulated by a legal and administrative framework (UN, 2004), is a critical element in the alleviation of poverty. Other scholars have categorised it into legal (de jure) (titling), de -facto (recognised as legitimate without title), perceived (people's perceptions on security) or as a continuum of rights ranging from informal to formal rights (Uwayezu and de Vries , 2018 , Van Gelder ,2009). It is however increasingly precarious as evidenced by mass evictions of slum and squatter settlements in various cities (Barry, 2015). Moreover, most of the 1 billion currently living in slums, have no security of tenure (UN HABITAT, 2016, 2007). It has been argued therefore that securing it contributes to improvement in informal settlements because of its catalytic effect (UNHABITAT and GLTN, 2011, Cities Alliance, 2004). These include, private investment in housing, access to credit, increased property values, neighbourhood improvement, and increased infrastructure investment since the government is more willing to invest when settlements are tenure secure (Payne and Durand-Lasserve, 2013, De Soto, 2000, Turner, 1968).

Theoretical and empirical studies have however shown that tenure alone is not adequate in solving challenges in informal settlements. In Peru and Brazil, titling had little impact on credit access (Fernandes, 2011), on the labour market in the Philippines (Velasco, Regadio, and Girado, 2014), on housing conditions and infrastructure in Peru, (Almansi, 2009) on livelihoods and living conditions in South Africa (Huchzermeyer and Karam, 2008) on incomes and employment in Buenos Aires and Peru (Galiani and Shargrodsky, 2005, Ananya, 2005). Moreover, it has been argued that tenure security (titling) may lead to gentrification (Payne and Durand- Lasserve, 2013).

\subsection{Infrastructure}

Infrastructure has been defined variously. Fulmer (2009) defines it as "the physical components of interrelated systems providing commodities and services essential to enable, sustain, or enhance societal living conditions" (Fulmer 2009). Though critical, it is estimated that almost two-thirds of African urban dwellers are living in slums characterized by deficient infrastructure (UN, 2011) leading to the deplorable conditions. It is therefore seen as an essential element in improving informal settlements and reducing its incidence (AfDB, 2013, UN Habitat, 2011, World Bank, 2005,) improving slum "image" and environmental conditions (Amis, 2001), improving quality of life for settlement residents (Kessides, 1997), connection to core economic activities, improved health and positive impact on income and welfare of the poor (Pritti, 2015, Komives, 2005, Calderón, and Servén, 2004). It has been argued therefore that infrastructure should not only be the primary goal and central component of upgrading projects (Gulyani \& Connors, 2002) but it should rank at the top of the poverty reduction agenda.

However, studies have also shown that infrastructure did not address all the problems faced by the urban poor especially assets, livelihoods, and ill-health in India (Amis 2001). In Thailand on Baan Mankong slum and squatter upgrading program, it did not address the deeper aspects of livelihoods, institutions, power to make decisions, initiate and manage upgrading projects, capabilities, social networks and participation (Boonyabancha 2005) concluding that the physical form of the upgrading is not the issue - or the problem.

\subsection{Livelihoods}

A livelihood, in its simplest sense, is a means of gaining a living (Chambers and Conway, 1992). It is precarious for residents in informal settlements. Slum residents are often excluded from economic opportunities, as evidenced by high unemployment rates in slums (Shah, 2014, Gulyani and Talukdar, 2008) and those who are able to find work are often employed in the informal sector, do temporary or casual labor and receive inadequate or inconsistent incomes (Shah, 2014, Mitlin, 2011). In addition, the high cost of food, housing, transport, health, education, and water in slum areas impact the ability of the urban poor to rise out of poverty. On education, for example, studies indicate that a majority of parents settling in slums postpone sending their children, especially girls, to school, until they are able to manage other expenses, such as food, rent, and transport (UN 2006/2007, 2010/2011). It is no wonder then that for most poor people in cities when asked what they need most, they say jobs or money (Grant et al, 2004).

However, upgrading has largely focused on physical aspects and not these softer areas of livelihoods. Yet it is people's ability to effectively transform these assets into income, food or other necessities that can enhance productivity and constitute a 'resilience' strategy (Moser, 2008). Other scholars have thus argued for livelihoods approaches that place people at the centre of development and focus on empowering the poor to build on their own opportunities, (Haidar 2009). Conversely, livelihoods should include a much wider range of endeavours (Pritti, 2015) to support it.

\subsection{Tenure, infrastructure and livelihoods linkages}

It is emerging from the above discussions that tenure security, infrastructure and livelihoods improvements are key elements in upgrading but each is not adequate, on its own, to improve living conditions in informal settlements. This has led to some scholars alluding to a relationship between infrastructure provision and tenure security though 
authors differ on the nature of tenure security- de jure or de facto. A number of studies have pointed out that provision of infrastructure did not provide tenure security. In Ghana, a study showed that though very beneficial to residents of the area, infrastructure brought to the fore, serious land tenure challenges where construction of civil works on the project in some parts had to be put on hold for a while owing to disputes over the ownership of the land earmarked for construction (WaterAid, 2009). For other scholars, secure tenure is a prerequisite for the provision of basic services (Durand-Lasserve , 2006). Conversely, it has been argued that the lack of formal infrastructure facilities is a condition arising from the absence of tenure (Cromwell and DFID (2002). However, a contrary view is that secure tenure contributes peripherally to the physical environments in human settlements (Makachia, 2011, Nyametso, 2010). For Durand -Lasserve and Payne (2006) the evidence is mixed: - In Colombia, access to infrastructure is available to all citizens who can pay for services irrespective of tenure status, in Peru, titling has not improved significantly access to services, in Egypt, tenure status is unrelated to the provision of basic services and in India, households with registered leaseholds showed better access to water and sanitation and individual electricity connections (Durand -Lasserve and Payne 2006). What is the experience in Kenya?

Some scholars have argued for a dual entry approach to slum upgrading- tenure and infrastructure provision (Collin 2012, Gulyani and Talukdar, 2008, Durand-Lasserve, 2006). In concurrence, Collin (2012), from his research in Tanzania, argued that infrastructure upgrading has a positive effect on tenure and that there is a potentially important, complementary, role for land titling alongside infrastructure projects, as a means for households both to capitalize gains from infrastructure investments, as well as to address uncertainty inherent in the growth process of a rapidly urbanizing environment. Both tenure security and infrastructure have a catalytic effect on livelihoods but yet it is critical that people have the capabilities to effectively transform these into livelihoods strategies that are sustainable, resilient and can enhance their well-being as well as cope with and recover from shocks and stresses (Carney, 1999).

It is noteworthy that there are limited studies that have specifically analyzed the interlinkages between tenure security, infrastructure and livelihoods in upgrading, a gap that this study sought to investigate.

\section{Methodology}

The study was undertaken in Eldoret town, the fifth largest town in Kenya located in Rift Valley experiencing high urban growth rate. The case study settlements being Huruma, Munyaka and Kamkunji informal settlements located within the town boundaries that over time benefitted from upgrading and thus presented an opportunity to investigate the three factors of tenure, infrastructure and livelihoods. The study used household survey, focus group discussions, key informant interviews, and observations to gather data. A probabilistic random sampling was done and ArcGIS was used to generate random points to obtain a sample of 200 households spread in the three settlements according to each settlement population thus achieving 100 households in Huruma, 60 in Munyaka and in 40 Kamkunji. Focus Group Discussions (FGD) comprising opinion leaders, tenants and landlords/structure owners were held separately in each of the settlements while key informant interviews were held with institutions and key community leaders that were purposefully selected. Further data was collected through observations of the phenomena being investigated while secondary data was obtained from existing literature and documents from relevant agencies.

Data obtained was analyzed using both qualitative and quantitative techniques. Qualitative data was analyzed through the form of descriptions and explanations necessary to provide an understanding of the linkages of tenure security, infrastructure and livelihoods. Data obtained from household survey was analyzed using Statistical Package for Social Sciences (SPSS) to generate descriptive statistics such as averages, percentages and proportions, frequencies and cross-tabulations. In addition, the study used Chi-Square Test of Independence (association) at a0.05 significance level, to determine whether there was an association between categorical variables of tenure security, infrastructure, and livelihoods. The following chi-square test formula was used:

$$
\chi_{c}^{2}=\sum \frac{\left(\mathbf{O}_{\mathrm{i}}-\mathrm{E}_{\mathrm{i}}\right)^{2}}{\mathbf{E}_{\mathrm{i}}}
$$

The subscript "c" is the degrees of freedom, "O" is the observed value and $\mathrm{E}$ is the expected value.

\section{Results and discussion}

\subsection{Existing tenure, infrastructure and livelihoods in case study settlements}

The study found that the three case study settlements of Huruma, Munyaka and Kamkunji had benefitted from tenure and infrastructure upgrading indicated by $94 \%$ in Huruma, $86 \%$ in Munyaka and 97.5\% in Kamkunji. Information from key informants in the settlements and the Ministry in charge of land, tenure security processes commenced in the $60 \mathrm{~s}$ and concluded in the 90s with the issuance of titles to dwellers in Huruma and Kamkunji but the processes were still ongoing in Munyaka at the time of research, more than 30 years after the process began. On infrastructure according to focus group discussions in the respective settlements , there were 
water, electricity and murram roads provided in all the three settlements but these were isolated and stand-alone provisions and were therefore not adequate. In 2012-2016 there was more comprehensive upgrading of roads, water and sanitation and floodlights in the three settlements provided by the Government with funding from international institutions. Tenure and infrastructure, however, were undertaken individually and not simultaneously indicated by $88.9 \%$ in Huruma, $68.8 \%$ Munyaka and $85.7 \%$ in Kamkunji. , However, though livelihoods existed, there was no direct upgrading support to livelihoods.

The existing tenure security according to findings of this study was mainly rental, land tenure and share certificates. Rental tenure was the most prevalent in all the three settlements. In Huruma 75.5\% were rent-paying tenants, $74.6 \%$ in Munyaka and $62.5 \%$ in Kamkunji. Land tenure comprised of landowners who had freehold legal tenure which was the prevailing form and leasehold tenure but only for Huruma and Kamkunji with $75 \%$ and $85.7 \%$ respectively had freehold and leasehold indicated by $10 \%$ and $11 \%$ respectivley. Munyaka, on the other hand, was yet to get titles despite settling in the land more than 30 years ago with most plot owners, $62.5 \%$, still holding share certificates as proof of ownership. On infrastructure, the study findings showed that the three case study settlements had been upgraded. According to the household survey, the type of infrastructure in Huruma settlement were roads, water, sewerage and electricity indicated by $62.2 \%, 82.8 \%, 72.0 \%$ and $89.2 \%$ respectively. In Munyaka infrastructure upgraded included roads, $51.6 \%$, water $66.7 \%$, sanitation (latrines) $84.7 \%$, electricity, $86 \%$. In Kamukunji settlement infrastructure readily available were roads $82.5 \%$, stormwater drainages $65.8 \%$, walkways $65.8 \%$, water $81.6 \%$, lighting $72.5 \%$, and electricity $97.4 \%$. For all the settlements garbage disposal was minimal.

Livelihoods were limited in the three settlements. On skills, only 38.8\%in Huruma, $40.6 \%$ in Munyaka and even lower in Kamkunji at $27.5 \%$ had formal skills. However, a majority had education, $93.9 \%$ in Huruma, 54.2\% in Munyaka, and $87.5 \%$ in Kamkunji. On Housing, units were mainly permanent in Huruma, indicated by $59.2 \%$,but less in Munyaka, 37.3\% and Kamkunji only 27.5\% .In respect to the assets owned, the majority had household goods with a small proportion owning land. Livelihood activities included employment both formal and informal 32.7\%, 35.6\%,22.5\% in Huruma, Munyaka and Kamkunji respectively. Business/commercial trade at $20.4 \% 22.0 \%, 42.5 \%$, respectively,.On average household income, in Huruma, 20.4\% indicated an income of Kshs. 18,001-22,500, 15.3\% had an income of Kshs. 9,001-13,000 or Kshs. 13,001-18,000, and 12.2\% had an income of Kshs. 22,501-30,000 while 10.2\% had an income of Kshs. 6,001-9,000. In Munyaka settlement majority of the households, 30.5\% had an income of Kshs. 6,001-9,000, 22.0\% had Kshs. 9,001-13,000, and 16.9\% had Kshs. 3,001-6,000 while 11.9\% had Kshs. 13,001-18,000. In Kamkunji, most households, 22.5\% had an income of between Kshs. 13,001-18,000, 15.0\% with Kshs. 6,001-9,000 and Kshs. 9,001-13,000, 12.5\% with Kshs. 22,501-30,000 while $10.0 \%$ had Kshs. 18,001-22,500 or Kshs. 30,001-37,500, pointing to generally lower incomes in Kamkunji compared to Huruma and Munyaka.

From these data and analysis, key issues that emerged are the single sector silo approaches of the two interventions. Tenure was implemented over a 25-35-year period and at different times from the infrastructure. The piecemeal infrastructure provision was done by multiple but uncoordinated agencies in the 70s-90s were not impactful since the government had to provide more comprehensive infrastructure in later years. Bahr, (2012) had a similar finding of silo provisioning typically delivered by separate entities and not coordinated, as well as being isolated from other urban planning processes leading to, according to Oliveira, et al (2015), failure to achieve longterm objectives. This is unstainable that there is a need for integrated approaches. This should incorporate livelihoods. The findings of this study showed that livelihoods upgrading was neglected and have remained precarious despite tenure and infrastructure provision. Similarly, Jones (2017), found that livelihoods are given limited consideration in upgrading. However, this study argues that empowerment and access to livelihoods are more likely to give informal settlement dwellers greater livelihood options with which to enhance their living and reduce poverty requiring that upgrading approaches are re-focused to incorporate aspects of livelihoods. This study suggests an integrated nexus approach that addresses tenure, services and livelihoods together in upgrading as opposed to the current largely silo and sectoral approaches.

\subsection{Tenure-Infrastructure-Livelihoods nexus in upgrading}

The framework of analysis on tenure-infrastructure-livelihoods linkages is based on the nexus analysis approach advanced by Scollon and Scollon (2004) but has since been promoted as an emerging global development paradigm and research agenda (Middleton, 2015 et al) and recently used under the SDGs (Leck, et al, 2015, Weitz, 2014) to analyse linkages, the trade-offs and synergies between goals to promote the integration across sectors for sustainable development. This has been used to identify and analyse the process and functional relations underlying the upgrading interventions of tenure security, infrastructure and livelihoods. For each case study settlement, the key interplays examined are between tenure and infrastructure, tenure and livelihoods and infrastructure and livelihoods. As a background, the study first established the existing status of tenure , infrastructure and livelihoods improvement. These are discussed below. 


\subsubsection{The interplay of tenure security and infrastructure in upgrading}

The study findings showed that tenure security and infrastructure were implemented independently but nonetheless, the study found that tenure security interplays with infrastructure in various ways that are both beneficial and detrimental to the improvement of informal settlements.

Study findings showed that tenure and infrastructure are functionally interlinked. Data analysis using chisquare test and cross-tabulations on tenure and various types of infrastructure showed a mixed set of functional interlinkages between tenure security and infrastructure in the informal settlements of Huruma, Munyaka and Kamkunji with evidence that infrastructure (water, sanitation and electricity) is dependent on tenure security while for other infrastructure (roads, drainage, walkways) evidence was not adequate to suggest that they were dependent on tenure security, as discussed below.

Chi-square data analysis showed that the nature of water source is dependent on the tenure security in the three case study settlements and cross tabulations showed that majority with the security of tenure, $73.9 \%$ in Huruma, 53.3\% in Munyaka and 59\% in Kamkunji having piped water from the shared compound tap but only $8.7 \%, 6.7 \%$ and $12.8 \%$ respectively of those without tenure security have the same. None of those without the security of tenure had piped water from a private individual connection inside the housing unit or borehole in the compound in all the three settlements. Similarly, there is a linkage between tenure security and sanitation. Most households with tenure security have some form of sanitation indicated by $69.6 \%$ in Huruma, $86.7 \%$ in Munyaka and $69.2 \%$ in Kamkunji having a shared a pit latrine and bathroom inside the compound, 13\%, $6.7 \%$ and 5.1\% respectively have a toilet and bathroom in the house while $4.3 \%$ in Huruma and $23.1 \%$ in Kamkunji are connected to a sewer line but none is connected in Munyaka due to lack of sewer line. On the contrary, those without the security of tenure have minimal sanitation with only $4.3 \%, 6.7 \%$ and $5.1 \%$ having private toilet and bathroom inside the house or shared pit latrine and bathroom outside the house but within the compound and none are connected to the sewer. Electricity was also found to be interlinked with tenure security determined by the Fisher's Exact test. The majority, 87\%, in Huruma, 73.3\% in Munyaka and 59.0\% in Kamkunji with the security of tenure have formal electricity connection in their housing units but those without the security of tenure, only $4.3 \%, 6.7 \%$ and $12.8 \%$ respectively have formal or informal electricity connection to the housing unit. However, on roads, the chi-square test revealed that the nature of roads is independent of the security of tenure in all the settlements though a cross tabulation shows that majority of those with the security of tenure had roads in the settlement.

Beyond these functional linkages, the study found that tenure and infrastructure processes interlinked but these linkages are often overlooked. According to key informants from the Ministries in charge of Lands and infrastructure, the tenure processes broadly entailed planning, surveying, valuation, registration and issuance of ownership documents. Infrastructure provision, on the other hand, entails project identification, feasibility studies, conceptual and detailed designs (feasibility, environmental and social impact, design), tendering and construction. Both processes required a form of community and stakeholder engagement and review of policy and legal framework. From the study findings and analysis, these processes of upgrading tenure and infrastructure are inextricably linked.

First there are processes that are common to both interventions and secondly, there are those that are reciprocal since they directly impact the processes of the other. The shared processes are mainly preliminary activities meant to lay the ground for the project whether infrastructure or tenure security upgrading. It includes activities such as community and stakeholder engagement, baseline surveys (socio-economic surveys, physical mapping, feasibility studies), Environmental Impact Assessments (EIA) Environmental and Social Impact Assessments (ESIA) and Relocation Action Plans. These are necessary for establishing the existing situation, the needs and priorities of the community, establishing the feasible options, the magnitude of the project impact and mitigation measures, strategies and actions on the relocation of services and relocation of affected persons including their compensation all of which apply to both tenure and infrastructure. These processes could ideally be done once to serve both purposes of infrastructure and tenure. However, in the case study settlements, these processes proceeded independently, because of the sector-specific approaches in the implementation of these interventions.

From the study findings, there were processes that are reciprocal and have an impact on either of the processes. For example, a Local Physical Development Plan prepared under tenure security processes influences infrastructure socio-economic surveys, feasibility studies, community infrastructure priorities, slum upgrading plans, engineering designs, Environmental Impact Assessments, relocation action plans, compensation of affected persons, construction of infrastructure, operation and maintenance. This clear interaction requires a multisector concurrent approach to tenure and infrastructure. The fact that both tenure and infrastructure are intertwined and equally vital begs for strategies that address both issues simultaneously or in parallel. Scholars have argued that these are inter-dependent and instead of choosing one over the other, they should be acted upon simultaneously (Gulyani, S. et al ,2008, 2012)

From the case study settlements of Huruma, Munyaka and Kamkunji however, tenure and infrastructure processes proceeded independently through single sector silo approaches. As a result, common processes that were 
required in both tenure security and infrastructure were undertaken separately with no linkage, leading to duplication and waste of resources and worse still, as described above by the residents of these settlements led to, well-meaning infrastructure projects undermining tenure security and vice versa. This study argues for a multisector approach that incorporates livelihoods to these physical interventions and allows complementarity and synergies in these interlinked interventions for cost-effectiveness, efficiency and realization of greater impact and sustainability

\subsubsection{The interplay of tenure security and livelihoods in upgrading}

This study found that tenure security and livelihoods interlink. On incomes, those with security of tenure had higher incomes than those without determined by a Likelihood Ratio statistic of $0.021<0.05$ in Huruma and a Likelihood Ratio statistic of $0.016<0.05$ in Kamkunji but for Munyaka ,unlike Huruma and Kamkunji, the data analysis showed that there is no clear evidence of a relation in the case of the tenure security and household incomes determined by the Likelihood Ratio statistic of $0.740>0.05(\alpha-$ significance level). Those with tenure security had permanent housing units determined by a Likelihood ratio $0.021<0.05 \alpha$ - significance level, in Huruma settlement and Likelihood ratio $0.044<0.05 \alpha-$ significance level in Munyaka . Similarly, tenure security determined the nature of assets owned determined by a Likelihood ratio of $0.029<0.05 \alpha-\operatorname{sig}$ level in Huruma.

However, security of tenure did not determine the nature of employment determined by Likelihood ratio $0.097>0.05$ in Huruma and in Munyaka determined by the Fishers' Exact test statistic of $0.400>0.05 \alpha-$ significance level. On education, data analysis for the three settlements showed that the level of education is not interlinked to the tenure Security determined by the Fisher's exact test $0.114>0.05 \alpha-$ sig level in Huruma, Fisher's exact test $0.400>0.05 \alpha$ - sig level in Munyaka Fisher's exact test $0.114>0.05 \alpha-$ sig level.in Kamkunji. Similarly, on skills, data analysis showed that possession of skills is independent of the tenure security status determined by the Fisher's exact ratio $0.605>0.05 \alpha-$ sig. level in Huruma, Fishers' Exact test statistic $0.791>$ $0.05 \alpha$ - sig. level in Munyaka and Fisher's exact ratio $0.302>0.05 \alpha-$ sig. the level in Kamkunji.

The processes of securing tenure were also found to have an impact on livelihoods in the informal settlements of Huruma, Munyaka and Kamkunji. The initial secure freehold tenure on agricultural land had the positive effect of granting security to the white settlers who used the lands for their own livelihoods but negatively affected the indigenous communities. During this pre-independence period, the local people were dispossessed of their livelihood security (Odhiambo 2006, Boone 2009). At the advent of independence, these were transferred to Africans based on a willing seller and willing buyer principle. According to key informants, land buying companies were among those who bought land upon which Huruma, Munyaka and Kamkunji settlements sprawl today. Informal subdivisions and transactions, construction of rows and rows of haphazard houses, lack of public utilities such as schools, markets, access roads and other basic services degenerated the previous farmlands into informal settlements. These conditions exposed the dwellers to insecurities and vulnerabilities and subsequently precarious livelihoods.

According to Focus Group discussions, key informant and existing literature, the government intervened in these settlements in the 90s to restore the security of tenure. The Uasin Gishu Physical Planning Department district office prepared advisory plans for Huruma/Mwenderi, Kamkunji and Munyaka. The advisory plans were aimed at providing a physical layout plan showing the orderly arrangement of various land uses that would maximize the use of land and to support the livelihoods or economic activities of poor households. This process and the subsequent surveying and issuance of titles (though the later took inordinately long in Huruma and Kamkunji and yet to be completed in Munyaka) had direct and indirect impacts on livelihoods. Apart from securing the resident's assets and improving their houses, their livelihoods benefitted from access to assets held in common such as roads of access and other public utility areas such as schools in the case of Huruma and Munyaka and market in the case of Kamkunji that were established by the Eldoret Municipal Council. This finding resonates with other scholars who have argued that tenure security that comes with the upgrading programme results in increases in the likelihood that households upgrade their homes, take out loans, plan to use savings for upgrading purposes in the future and obtain rental income through tenants." (Tissington, 2012)

On the other hand, formal protection through land title registration offers the maximum security of tenure but it is costly and the title registration has not produced the sort of increases in productivity and capital investment the proponents of the system promised (Kieyah and Kameri-Mbote, 2010). The delay and high cost in these processes had negative effects on livelihoods because their timely access to tenure security and opportunities thereof were constrained by the regulatory processes. As pointed out by scholars, livelihoods of urban poor are fragile and easily disrupted or threatened, even by well-intentioned actions by authorities (Housing Development Agency, 2014) that prevent low-income groups from engaging in activities that would otherwise enable them to make a living ( Jayaratne and Sohail 2005).

Further, livelihoods go beyond assets to include the people's capabilities (education, skills) and activities (employment and incomes) required for a means of living which in the case study settlements of Huruma, Kamkunji and Munyaka were not addressed alongside tenure security and infrastructure provision. There is need therefore to consider livelihoods in parallel with these so that lengthy and costly tenure security processes that may 
weaken livelihoods do not undermine the livelihoods. What is needed is an integrated approach that addresses the various needs in a holistic way.

\subsubsection{The interplay of infrastructure and livelihoods in slum upgrading}

The study findings showed that infrastructure and livelihoods are linked. The data obtained, when cross-tabulated, showed that $77.6 \%, 61.1 \%$ and $70 \%$ of the respondents in Huruma, Munyaka and Kamkunji respectively indicated that there are interlinkages between infrastructure and livelihoods. Data analysis showed that infrastructure contributes to the amount of household income in the settlement determined by Likelihood ratio of $0.037<0.05$ $(\alpha)$ in Huruma, a Likelihood ratio of $0.011<0.05(\alpha)$ in Munyaka and a Likelihood ratio of $0.008<0.05(\alpha)$ in Kamkunji all at 5\% significance level. There is a linkage between infrastructure and housing, with those with infrastructure having permanent housing units determined by Likelihood ratio sig value is $0.001<0.05(\alpha)$ in Huruma, and a Likelihood ratio sig value of $0.003<0.05$ (a) in Munyaka. There was also an interlinkage between the infrastructure and the household assets based on a Likelihood ratio sig. value of $0.001<0.05$ (a). Further analysis yields a Cramer's V value of 0.536 , which suggests a very strong association between infrastructure and assets for respondents in Huruma settlement. In Munyaka, Similarly, there is an interlinkage between the infrastructure and the household assets based on the Likelihood ratio sig. value of $0.001<0.05(\alpha)$. Further analysis yielded a Cramer's V value of 0.554 that suggested a very strong association between infrastructure and assets in Munyaka settlement.

However, infrastructure does not determine the households' form of employment determined by the Likelihood ratio sig. value is $0.968>0.05(\alpha)$ in Huruma, sig. value of $0.615>0.05(\alpha)$ in Munyaka and sig. value of $0.851>0.05(\alpha)$ in Kamkunji, at 5\% significance level. This was attributed to the fact that the infrastructure in the settlements was newly built and the long-term effects were yet to manifest fully. Similarly, there was not sufficient evidence to link infrastructure to skills, determined by Chi-Square $p$-value is $0.816>0.05$ $(\alpha)$ in Huruma and in Munyaka determined by the Fisher's Exact test statistic of $0.641>0.05(\alpha)$. Infrastructure did not determine education level as well, based on the Fisher's Exact test statistic of $0.614>0.05(\alpha)$ in Huruma but in Munyaka, a Chi-Square test yielded a p-value of $0.019<0.05(\alpha)$ which pointed to infrastructure determining education however further analysis gave a Phi value of 0.237 meaning the strength of association was weak.

In addition to these, study findings found that infrastructure-upgrading pathways have generated various livelihood dynamics as dwellers sought to cope with the shocks generated by physical changes in their environments. As discussed in section 4.1 above, the approach to the provision of infrastructure was for a longtime single sector, piecemeal and uncoordinated approaches until the period 2014-2016 when there was an attempt by the Government to provide comprehensive infrastructure in the three settlements of Huruma, Munyaka and Kamkunji. The outcome of the silo approach in the earlier years was minimal impact on livelihoods. The findings of a study undertaken in informal settlements in Eldoret (Huruma, Munyaka and Kamkunji) in 2012 showed that only $10 \%$ of households had access to piped water, $10 \%$ had access to home toilet and only $13 \%$ had access to usable roads during the rainy season and 53\% were below the poverty line (World Bank, 2014).

In the 2014- 2016, infrastructure upgrading in the three settlements of Huruma, Munyaka and Kamkunji, was more comprehensive. According to key informants, the infrastructure was multi-sector and was provided more or less simultaneously. According to key informants, the procedures and processes were equally wide-ranging and each of them had an impact on livelihoods as shown on table 1 below. 
Table 1: Infrastructure pathway, impact on livelihoods and outcomes

\begin{tabular}{|c|c|c|}
\hline Pathway & $\begin{array}{l}\text { Impact on } \\
\text { livelihoods }\end{array}$ & Outcome \\
\hline $\begin{array}{l}\text { Preliminary } \\
\text { community mobilization, socio-economic } \\
\text { surveys and feasibility studies, community } \\
\text { infrastructure priorities; engineering } \\
\text { designs; environmental impact assessment; } \\
\text { relocation action plan; bidding documents; } \\
\text { tendering and procurement of contractors. }\end{array}$ & LOW & $\begin{array}{l}\text { + No immediate disruption of livelihoods. } \\
+ \text { Community buy-in/ownership } \\
\text { - Long-term effect of delays, limited } \\
\text { menu/options }\end{array}$ \\
\hline $\begin{array}{l}\text { Implementation } \\
\text { Relocations, site clearing and construction } \\
\text { of infrastructure i.e. roads, walkways, } \\
\text { drainage, lighting, water and sanitation }\end{array}$ & $\begin{array}{l}\text { MODERA } \\
\text { TE }\end{array}$ & $\begin{array}{l}+ \text { Employment and business from civil works } \\
\text { - Loss or reduced livelihoods due to relocations } \\
\text { - Loss/disruption of services i.e. water, electricity, }\end{array}$ \\
\hline $\begin{array}{l}\text { Operation } \\
\text { Transport (vehicles, motorcycles), } \\
\text { Lighting, Water and Sewer connections and } \\
\text { payment of bills, drainage }\end{array}$ & HIGH & $\begin{array}{l}\text { + Improved road transport } \\
+ \text { Increased access to the settlement } \\
+ \text { Increased security and safety due to lighting } \\
+ \text { Improved business } \\
+ \text { Improved housing } \\
+ \text { Improved water and sanitation } \\
+ \text { Reduced flooding } \\
+ \text { Improved environmental conditions } \\
\text { - High costs (water and power bills) } \\
\text { - Increased rent leading to market evictions } \\
\text { - Accidents }\end{array}$ \\
\hline
\end{tabular}

As shown in the illustration, infrastructure pathways have an impact on livelihoods. From Focus Group discussions, it emerged that during the preliminary phase community consultations were done but they felt that it was not adequate and not all priorities of the community were included in the final designs due to government and donor limited infrastructure menu. This has a long-term effect of limiting livelihoods in the softer areas of education, health and business. The argument of this thesis is that improvements can be achieved through integrated multi-sector approaches by coupling infrastructures with improvements in tenure security and indirectly strengthening livelihoods. These should be conceptualized at the design/preparatory stage of projects and programs.

During the second phase, it emerged from findings that there were disruptions to livelihoods due to relocations of both persons and services especially water lines, electricity and sewer lines to pave way for various infrastructure. This finding is similar to other research findings where it was found that fixed urban infrastructure is complicated and socially disruptive, especially if it means retrofitting after the land has already been settled and built upon (Turok, 2016). On the positive side, however, the construction of infrastructure provided both temporary employment and business.

The highest impact on livelihoods, however, came when the infrastructure was operationalized. Lighting has increased working hours; roads have improved transportation for goods and people, water and sanitation have improved cleanliness and health and reduced incidence of diseases all of which has improved the living conditions. This builds on what other scholars have pointed out. According to Rakodi and Lloyd-Jones,(2014) the benefits of access to infrastructure and services by poor residents in urban areas are direct, in terms of improved health, increased knowledge, easier working and living conditions, and access to income-generating opportunities through transport infrastructure and services. They are also indirect in that access to a range of basic services releases income and other resources, such as time, for other purposes (Rakodi and Lloyd-Jones, 2002).On the negative side, high utility costs, rents and increased land values have triggered gentrification. This observation is in tandem with the theories on market evictions which are seen to create a cycle of poverty where the poorer members are forced out by market dynamics to poorer areas (Durand Lesserve 2007). The argument for this study is the need for nexus approaches that address both physical improvements and livelihoods improvements to minimize or altogether remove constraints that lead to market evictions.

\section{Conclusion}

Provision of tenure and infrastructure have been viewed as the traditional approaches to upgrading and though they can improve living conditions in informal settlements, as was the case in the case study settlements, there is a need to go beyond these and include interventions that strengthen the livelihoods of the poor. This will assist them in effectively transforming tenure security and infrastructure into employment, income, food, housing, health or other livelihood necessities that can bring about transformation in their lives and the environment they live in.

This study finding suggests that there exists a nexus in tenure security, infrastructure and livelihoods in the 
upgrading of informal settlements. These interventions are intertwined both in processes and outcomes calling for a rethink in the current sectoral but unsustainable approaches that lose out on the potentials of synergies and minimization of conflicts and cost if these were addressed concurrently. From the study findings, it is challenging to address infrastructure provision without tenure security and vice versa while livelihoods must of necessity be adequate to support both infrastructure and tenure security for impact and sustainability of upgrading efforts. In view of this, understanding the linkages among the interventions of tenure, infrastructure and livelihoods in upgrading processes is critical for policy and practice of upgrading. In conclusion, therefore, integrated tenure security-infrastructure-livelihoods upgrading approach has the potential to improve living conditions and quality of life thus contribute to meeting SDG's goals on ending poverty in all its forms and making cities and human settlements inclusive, safe, resilient and sustainable, respectively.

Author Contributions: This manuscript is a part of an ongoing $\mathrm{PhD}$ research. Ms Mang'ira who is the $\mathrm{PhD}$ candidate, contributed to all sections under the guidance of two supervisors namely Dr Musyimmi Mbathi, who also made contributions, revised and edited the whole manuscript and Dr Samuel Obiero who reviewed and made a further input to the manuscript.

Acknowledgements. The authors gratefully acknowledge the support of reviewers of this manuscript and for their useful input and appreciation to publishers for publishing this manuscript.

Funding: This research received no external funding.

Conflicts of Interest: The authors declare no conflict of interest.

\section{REFERENCES}

African Development Bank (2018) African Economic Outlook 2018. African Development Bank

Almansi Florencia, (2009), Regularizing land tenure within upgrading programmes in Argentina; the cases of Promeba and Rosario Habitat. Environment and Urbanization. Sage

Ananya, R. (2005) Urban Informality: Toward an Epistemology of Planning. Journal of the American Planning Association, Vol. 71, No. 2 Chicago, IL. Sage Journals.

Amis, P. (2001) Rethinking UK aid in urban India: reflections on an impact assessment study of slum improvement projects. Environment and Urbanization, Vol. 13, No 1 of April 2001. Published by SAGE.

Barry, M. (2015) Property theory, metaphors and the continuum of land rights. UN-HABITAT and GLTN.UNON, Nairobi.

Boonyabancha, S. (2005) Baan Mankong: going to scale with "slum" and squatter upgrading in Thailand. Environment and Urbanization Vol. 17 No 1 April 2005. Published by SAGE.

Calderón, C. and Servén, L. (2004). The Effects of Infrastructure Development on Growth and Income Distribution. World Bank, Washington, D.C.

Chambers and Conway (1991) Sustainable rural livelihoods: practical concepts for the 21st century, IDS Discussion Paper 296, IDS, Brighton

Cities Alliance (2008) Alagados: The Story of Integrated Slum Upgrading in Salvador (Bahia), Brazil. The Cities Alliance.

Collin, M. et al (2012) Slum-Upgrading in Tanzania: Public Infrastructure and Private Property Rights. Working Paper. International Growth Centre. London School of Economic and Political Science, London.

De Soto, H., (2000). The Mystery of Capital: Why Capital Triumphs in the West and Fails Everywhere Else. Bantam Press, London.

Devas, N. P, Beall, J., Grant, U., Mitlin, D., Nunan, F. and Rakodi, C. (2004) Urban Governance and Poverty in the Developing World. London: Earthscan.

Ducrot, R. et al, (2010), Integrating land tenure, infrastructure and water catchment management in São Paulo's periphery: lessons from a gaming approach. Environment and Urbanization. International Institute for Environment and Development (IIED). Vol. 22(2): 543-560. www.sagepublications.com

Durand-Lasserve, A. (2006) Informal settlements and the millennium development goals: global policy debate is on property ownership. Global Urban Development Volume 2 Issue 1 March 2006

Estache, A. and Fay, M. (2009) Current Debates on Infrastructure Policy. Working Paper No. 49.

The International Bank for Reconstruction and Development / The World Bank Washington, DC.

Fernandes, E. (2011) Regularization of Informal Settlements in Latin America. Lincoln Institute of Land Policy, Brazil

Field, E. (2005) Property rights and investment in urban slums. Journal of the European Economic Association. $3(2-3): 279-290$

Fulmer, J. (2009). "What in the world is infrastructure?" PEI Infrastructure Investor (July/August): 30-32.The World Bank,

Galiani, S. and Shargrodsky, S. (2005), Property rights for the poor: effects of land titling. Working Paper No 29, Stanford Centre for International Development, Stanford University. 
Galiani, S. and Schargrodsky, E., (2016) The Deregularization of Land Titles. NBER Working Paper, No.22482.

Grant, U. (2004) Economic Growth, Urban Poverty and City Governance in Devas N, Amis, P, Beall, J, Grant, U, Mitlin, D, Nunan, F. and Rakodi C. (2004) Urban Governance, Voice and Poverty in the Developing World. Sterling, VA First published in the UK and USA in 2004 by Earthscan Publications Ltd. London.

Gulyani, S. Talukdar, D., Darby J. (2010) Poverty, Living Conditions, and Infrastructure access; A Comparison of Slums in Dakar, Johannesburg, and Nairobi. World Bank

Haidar, M.(2009)Sustainable livelihood approaches the framework, lessons learnt from practice and policy recommendations. Economic and Social Commission for Western Asia (ESCWA)

Hope K. R. (2011) Infrastructure Constraints and Development in Kenya. An Analytical Review. Journal of Infrastructure Development. Vol 2, Issue 2, 2010

Huchzermeyer, M. and Karam, A. (2006) Informal Settlements: A Perpetual Challenge? Juta and Company Ltd.

Kameri-Mbote, P. (2016) Kenya Land Governance Assessment Report. World Bank Document documents.

Kessides, C. (2005), The Urban Transition in Sub-Saharan Africa: Implications for Economic Growth and Poverty Reduction, Africa Region Working Paper Series No. 97 World Bank

Kieyah, J. \& Kameri-Mbote, P. (2010) Securing property rights in land in Kenya: Formal versus informal. Published in Christopher Adam et. al. eds, Kenya Policies for Prosperity(Oxford: Oxford University Press, 2010), p. 309-328.

Leck, H. et al. (2015) Tracing the water-energy-food nexus: description, theory and practice. Geography Compass, 9 (8). pp. 445- 460. ISSN 1749-8198

Lucci, P. et al (2015) What works in improving the living conditions of slum dwellers. A review of evidence across four programmes. Overseas Development Institute. London

Majale, M. (2008) employment creation through participatory urban planning and slum upgrading: The case of Kitale, Kenya. Habitat International 32 (2008) 270-282

Mbathi, M. (2011) Integrating Geo-information tools in Informal Settlement Upgrading Processes in Nairobi, Kenya. A Thesis Submitted to Newcastle University for the Degree of Doctor of Philosophy ,Faculty of Humanities and Social Sciences School of Architecture, Planning and Landscape Newcastle University, UK.

Middleton, C. et al. (201 The rise and implications of the water-energy-food nexus in Southeast Asia through an environmental justice lens. Water Alternatives 8(1): 627-654

Mitlin, D. (2008) with and beyond the state and transformation for grassroots organizations -Co-production as a route to political influence, power. Environment and Urbanization, 2008. Sage Publications .http://www.sagepublications.com

Moser, C. (2008) "Assets and Livelihoods: A Framework for Asset-Based Social Policy”, in Assets, Livelihoods, and Social Policy, edited by Caroline Moser and Anis A. Dani (Washington, DC: The World Bank, 2008).

Nyametso, J. (2012) The link between land tenure security, access to housing, and improved living and environmental conditions: A study of three low-income settlements in Accra, Ghana, Norwegian Journal of Geography, 66:2, 84-98, DOI: 10.1080/00291951.2012.665079

Parry J. (2015) From slums to sustainable communities: the transformative power of secure tenure; Issue Paper on Secure Tenure for Urban Slums. Habitat for Humanity and Cities Alliance

Payne, G. and Durand-Lasserve, (2013) "Holding On: Security of Tenure - Types, Policies, Practices and Challenges"This research paper was prepared for an expert group meeting on Security of Tenure convened by the Special Rapporteur on 22-23 October 2012.

Payne, G. Piaskowy, A. and Kuritz L. (2014): Land tenure in urban environments: USAID http://usaidlandtenure.net.

Priti, P. et all, (2015) Infrastructure Provision, Gender, and Poverty in Indian Slums. World Development Vol. 66, pp. 468-486. Elsevier Ltd.

Richmond, A. et al (2018) Urban Informality and Vulnerability: A Case Study in Kampala, Uganda. Urban Science.

Shah, H.D. (2014) Slum Dwellers and Savings: Organizing for Change in Informal Settlements. A dissertation submitted in partial satisfaction of the requirements for the degree of Doctor of Public Health in the Graduate Division of the University of California, Berkeley, USA.

Syagga, P. (2011) Land Tenure in Slum Upgrading Projects, IFRA, Nairobi

The World Bank (2016) Kenya Urbanization Review. Washington, DC

The World Bank, (2015) Slum Upgrading Overview. World Bank

The World Bank, (2014) Kenya State of the Cities Baseline Survey: Overview Report: Volume I. World Bank and NORC at the University of Chicago

The World Bank, (2007) Rethinking Infrastructure for Development. World Bank Washington DC

Turok, I. (2016) Getting urbanization to work in Africa: the role of the urban land-infrastructure-finance nexus. Area Development and Policy,

Uddin, N. (2018) Assessing urban sustainability of slum settlements in Bangladesh: Evidence from Chittagong city. Journal of Urban Management 7 (2018) 32-42. (C) 2018 Zhejiang University and Chinese Association of 
Urban Management. Production and hosting by Elsevier B. $V$.

United Nations (2016) Global Sustainable Development Report 2016. Department of Economic and Social Affairs, New York, July.

UN-HABITAT and GLTN (2011) Innovative Urban Tenure in the Philippines: Challenges, Approaches and Institutionalization. UN, Nairobi

United Nations (2018)Tracking progress towards inclusive, safe, resilient and sustainable cities and human settlements : SDG 11 synthesis report high-level political forum 2018. UN, Nairobi.

United Nations (2014) World Urbanization Prospects; The 2014 Revision Highlights, UN, Nairobi

The World Bank (2016) Kenya Urbanization Review. World Bank,Washington, DC

United Nations (2017) The Sustainable Development Goals Report, 2017. United Nations, New York

United Nations (2016) Global Sustainable Development Report 2016. Department of Economic and Social Affairs, New York, July.

Uwayezu, E. and de Vries W. (2018) Indicators for Measuring Spatial Justice and Land Tenure Security for Poor and Low-Income Urban Dwellers. Land, MDPI, Basel, Switzerland.

Van Gelder, J.L. (2009) Legal tenure security, perceived tenure security and housing improvement in Buenos Aires: An attempt towards integration. Int. J. Urban Reg. Res. 2009, 33, 126-146. [CrossRef]

Velasco, M. Regadio, C. Girado, M. (2014) security of tenure, capital accumulation and quality of life for poverty alleviation. Social Development Research Center

Weitz, N. (2014)Cross-sectoral integration in the Sustainable Development Goals: a nexus approach. Stockholm Environment Institute. Stockholm, Sweden 